\title{
Dimension of Peace Culture Based on Al-Quran Values
}

\author{
Uman Suherman ${ }^{1}$, Nandang Budiman ${ }^{1, *}$, Dodi Suryana ${ }^{1}$, Eka Sakti Yudha $^{1}$, Aslina Binti Ahmad ${ }^{2}$, \\ Md Noor Bin Saper ${ }^{2}$
}

${ }^{1}$ Department of Guidance and Counseling, Universitas Pendidikan Indonesia, Indonesia

${ }^{2}$ Department of Psychology and Counseling, Universiti Pendidikan Sultan Idris, Malaysia

Received July 10, 2019; Revised August 24, 2019; Accepted September 7, 2019

Copyright $\bigcirc 2019$ by authors, all rights reserved. Authors agree that this article remains permanently open access under the terms of the Creative Commons Attribution License 4.0 International License

\begin{abstract}
This study has developed a model of peace based on al-Quran. Considering this situation, the Indonesia University of Education and the University of Education Sultan Idris in Malaysia undertook an initiative to jointly identify the local value that has contributed to the perceived and expected peace based on al-Quran in school communities. In this case, schools successfully establish a climate of peace, respect, compassion, fair, ethical and mutual respect. Violence varieties, which are done by teachers and students, have been already very alarming even in the category of emergency. Peace education is an effort to develop a culture of peace schools reinforced with religious values, that education has the capacity and the responsibility to lift humanitarian issues, about how people live side by side with others, and have concern for other human beings. This is indeed the true crisis in education. This study uses qualitative and quantitative approaches. A quantitative approach is used to test the effectiveness of school peace culture based on al-Quran values. A qualitative approach is used in the exploration of a dynamic psychology student. The subjects are Senior High School (SHS) and Vocational High School (VHS) students. The data with observation, and questioners peace culture are based on al-Quran.
\end{abstract}

Keywords Dimension, Peace Culture, Al-Quran Values

\section{Introduction}

This study is part of a series and follow-up research on service models pedagogical as well a counseling and guidance for the development of the mindset of the culture of peace in 2013, and international studies conducted by team Universitas Pendidikan Indonesia (UPI) and University Tampere Finland in 2014 concerning Meta-Analysis of Content of Local Rating In Pedagogic development Peace: Assessing Top Etnopedagogic Study in Perspective Indonesia-Finland "and" Exploration Values Mindset development of Peace in Education and Counseling: Lesson Learned Indonesia-Finland. The study's findings indicate that local values in Indonesia, particularly the Sundanese culture potential as a basis for the development of pedagogy of peace whereas teachers do not have a unified framework in the development of a peaceful mindset [1].

The importance of the culture peace in schools proposed by reference [2,3] describes the "essence of a new humanity" that represents the culture of peace will build the mindset, governance thought, and developmental approach towards peace [4]. In the context of the development mindset of the peace culture, the results from reference [1] found that the demands on the development of the higher peace culture mindset, even education has not responded strategically and systematically. Even more emphatic, reference [1] found in Indonesia (West Java) teachers do not have a unified framework in the development of a mindset of peace. It must be built to change teachers to have competence achievement as a teacher reached identity, so it will go in the mindset of peace and inner peace. Identity is built upon the understanding and internalization of the value system of the normativity of interest, the educational content, and pillars of the learning process [1, $3,4,5]$. Indonesian educational value system that must be internalized in oneself includes the understanding of human nature, humanity, and power.

The schools as an educational institution should ideally provide a climate that is filled with nuances of life of peace, respect, compassion, fair, ethical and mutual respect. Admittedly not a few schools were successful in establishing a climate of life, but lately in school contradictory phenomenon sticking to the surface. Varieties of violence that are done by teachers and students have been very alarming even in the category of emergency. Based on the data received by the violence of the National Commission for Child Protection in 2011-2016 indicate the year 2011 as many as 1,381 , in 2012 as many as 2,249 , in 2013 as many as 2,284, in 2014 as many like 3225, 2015, 
2511 and 2016 as many as 1452 [6]. The data were obtained only from those who reported, but because of various limitations, it is believed that there much more violence go unreported and therefore has not identified the type and number.

Based on statistics of Polis Diraja Malaysia (PDRM), in 2012 there were 3,700 students committing acts of violence, even in 2013 the increase is recorded as many as 7816 students commit acts of violence and acts of violence to occur because of adolescents weak character and morals. Data UNESCO shows that one in three girls and one in four boys in Indonesia have experienced violence [7, 8].

The efforts to transform the culture of peace are through peace education $[3,9]$. Peace education is not focused on problem-solving or conflict, peace education focuses on building mindset, and governance thinks teachers, students, and school stakeholders to create a culture of peace [10]. One of the values that should be strengthened in peace education that religious value. Their religious values represent the picture of consistency between belief in the religion as a cognitive element, a feeling of religion as an element of an effective and religion as an element of psychomotor behavior. Furthermore, it is an integrated complex of knowledge, feelings and religious action in a person.

Peace education based on religious values aims to develop learning that supports social cohesion, justice, and the preservation of the environment [11-14]. Social cohesion and mutual understanding between citizens involved in a dispute can be achieved through the provision of education that focuses a) Survival Skills (listening, following directions, avoiding conflict, using words that are good and interesting or talk openly, and respect themselves); b) interpersonal Skills (sharing, ask permission, to join in an activity, accepting others); c) Problem-Solving Skills (asking for help, asking for forgiveness, accept the consequences, deciding what to do); and d) Conflict Resolution Skills (kink in dealing with teasing, failure, accusations, unappreciated, and pressure) $[13,15,16]$.

The position of peace education in religious teachings, including the holy book of al-Quran, shows that human behavior is based on the values of religious teachings that can bring peace. Besides, peace can be viewed from two perspectives: the perspective of humanity (hablumminannaas) and the perspective of divinity (hablumminallah). They represent that peace is essentially derived from Allah Subhanahuwata'ala (SWT) because one of the names of the properties of Allah SWT is Assalaam that means almighty give safety and well-being $[5,9,17]$.

Indeed, education has the capacity and the responsibility to raise humanitarian issues, about how people live side by side with others, and have a concern to other human beings [7]. This is indeed the true crisis in education. The most significant way to develop a culture of peace based on al-Quran values is through peace education. Peace education is an education that thinks with humanitarian values, culture, and religion. As part of religious values, al-Quran values are forms of knowledge, belief, understanding, insight and ethical demands of human behavior in ecological communities.

In building a culture of peace effectively, competition and improved quality of behavior are needed to be done when individuals perceive and realize that the culture of peace must be done throughout life. There are three aspects that must be considered every individual in the life that is knowledge-based society (knowledge base learning) as a community of learning (learning society) that require education and training in a lifelong learning system.

The most significant way to develop a culture of peace based on Qur'an values is through peace education. Peace education is an education that is reinforced with humanitarian values, culture, and religion. As part of religious values, $\mathrm{Al}$ Qur'an values are forms of knowledge, belief, understanding, insight and ethical demands of human behavior in ecological communities.

The values of Al Qur'an is an entity that is not only seen from the aspect of the life of the world with ease and challenges, but should be thoroughly since man was created, turned, gave birth, switched off until a moment revived from death and happy world and the hereafter. Peace is reflected through the surah Al-Baqarah, verse 201" And among them there are those who say:" Our Lord, grant us good in this world and good in the Hereafter and save us from the torment of hell"

In building a culture of peace effectively, competition and improved quality of behavior are needed to be done when individuals perceive and realize that the culture of peace must be done throughout life. There are three aspects that must be considered every individual in the life that is knowledge-based society (knowledge base learning) as a community of learning (learning society) that require education and training in a lifelong learning system. This means that the learning process will always be attached to each individual life that takes place in the context of an ever-changing environment. Learning to live together is expected to combat the prejudices that may lead to disputes. Allah was advised by letter Ali Imran, verse 105 "And do not be like those who split apart and fight before they get a clear explanation (al-bayyinat)."

Based on these considerations, the research problem is whether the culture of peace based on the values of $\mathrm{Al}$ Qur'an can develop students' mindset and teachers' inner peace.

\section{Research Methodology}

This study used a qualitative and quantitative approach with a naturalistic paradigm because it makes it possible to work in a natural setting [18]. A quantitative approach was used to test the effectiveness of school peace culture based on al-Quran values. A qualitative approach was 
used in the exploration of a dynamic psychology student.

The study was conducted in two schools, SHS and VHS in the city of Bandung, Indonesia, where all the documents related to the previous research results are stored. The subjects were SHS and VHS students to determine the impact of the implementation of peace culture based on al-Quran values [18]. The data were taken by observation, and questioners peace culture based on al-Quran values. To observe, classroom observation was performed to witness the preservation of peace based culture of Al-Quran value.

To arrive at the final conclusion, the research data are interpreted based on personal reflection and the literature review. Considering the nature of qualitative research has attempted to avoid personal judgments and subjectivity to maintain the validity and reliability of this study. However, given that some data ere statistically processed, interpretation was also made in accordance with the quantitative data collected in the study. Hence, this study gathered simple quantitative data to support the qualitative data, as described in the next section.

\section{Results}

The results of the study examined empirical data on the peace-based culture of al-Quran values Students of SHS and VHS in Bandung Indonesia Academic Year 2018/2019.

\subsection{The Trend of Peace Culture Based on Al-Quran Values}

The results of the study describe empirical data on peace culture based on al-Quran values of students in several SHS and VHS in Bandung, Indonesia. The data can be seen in Table 1

Table 1. Student of SHS and VHS

\begin{tabular}{cccccc}
\hline & Demographics & SHS & VHS & Frequency & Percent \\
\hline Gender & Male & 84 & 159 & 243 & 59.12 \\
\hline & Female & 114 & 54 & 168 & 40.88 \\
\hline Total & & 198 & 208 & 411 & 100 \\
\hline
\end{tabular}

Table 2. Trends in Peace Culture Based on al-Quran Values

\begin{tabular}{cccccc}
\hline \multirow{2}{*}{ Levels } & \multirow{2}{*}{ Category } & \multicolumn{2}{c}{ SHS } & \multicolumn{2}{c}{ VHS } \\
\cline { 3 - 6 } & & Frequency & Percent & Frequency & Percent \\
\hline$<164$ & Very low & 0 & 0 & 7 & 3.36 \\
\hline $165-329$ & Low & 62 & 31.31 & 86 & 41.35 \\
\hline $330-660$ & Moderate & 113 & 57.07 & 115 & 55.29 \\
\hline $661-825$ & High & 23 & 11.62 & 0 & 0 \\
\hline$>826$ & $\begin{array}{c}\text { Very } \\
\text { high }\end{array}$ & 0 & 0 & 0 & 0 \\
\hline & Total & 198 & 100 & 208 & 100 \\
\hline
\end{tabular}

Based on the level of peace culture category, in general, the existing condition of class students in several SHS and VHS in the city of Bandung Indonesia showed that most of them were at a moderate level of $57.07 \%$ and as small at very low levels of $3.36 \%$. Specifically, the culture of peace based on al-Quran values of students of several SHS and VHS in the city of Bandung can be seen in Table 2.

Table 2 shows that the level of peace culture based on al-Quran values spreads to five levels with the first rank in the medium level category of 113 and 115 students, behavior shown by students, namely a) students have not shown optimal self-confidence, b) students show their openness with others, but still be shy, c) some students have shown sensitivity to the needs/desires of others, d) some students already trust each other and understand and cooperate/collaborate well, e) some students have respected each other, but have not been optimal in resolving disputes peacefully with fast or soon, and f) students have not been fully committed to creating a safe and peaceful environment.

The order second is in the low category as many as 62 and 86 students, the behavior shown by students is a) some students have not shown openness, politeness, friendliness, care, and support for others optimally, b) students have not shown an attitude of responsibility to resolve conflict, c) students have not shown collaboration well, correctly and effectively, d) students have not shown willingness to resolve conflicts and accept sincerely, e) students have not shown a sense of usefulness, active participation, and f) students have not shown respect and respect for others well.

Furthermore, the order third is in the high category as many as 23 people, the behavior shown by students is a) students have been open, belief, pay attention to others, feel sacrificial and friendly to others, b) students show sensitivity to the wants and needs of others, c) students believe and understand and can collaborate well and correctly, d) students are able to resolve conflicts without violence, but with a dialogue process, e) students show an attitude of caring towards others and f) students respect the potential of others constructively. Whereas seen from the proportion of student peace culture does not appear in the very low and very high-value category.

The research findings showed that the level of peace based culture of the al-Quran values spread to five levels with the first rank in the medium level category as many as 113 and 115 students, the second was in the low category as many as 62 and 86 students, the third was in the high category as many as 23 people, while seen from the proportion of the value of students' peaceful culture has not yet emerged in the very low and very high category.

The results of the study revealed the tendency of the dimensions of peace culture based on the values of the al-Quran, in general, the dimensions of peaceful culture of 
SHS and VHS students of several high schools in Bandung, Indonesia showed that some tendencies towards constrictive behavior were in the forgiving dimension with an average of 30.15 with a standard deviation of 16.85 , in detail can be seen in Table 3 .

Table 3. Trends in Dimensions of Peace Culture Based on al-Quran Values

\begin{tabular}{ccc}
\hline Students & Dimensions of Peace Culture & Average \\
\hline \multirow{3}{*}{ SHS } & Restrain & 30.15 \\
\cline { 2 - 3 } & Forgive & 29.00 \\
\cline { 2 - 3 } & Humble & 29.43 \\
\cline { 2 - 3 } & Collaboration & 23.52 \\
\hline & Communicate & 27.13 \\
\cline { 2 - 3 } & Peace & 29.57 \\
\cline { 2 - 3 } VHS & Restrain & 16.85 \\
\cline { 2 - 3 } & Forgive & 18.00 \\
\cline { 2 - 3 } & Humble & 17.57 \\
\cline { 2 - 3 } & Collaboration & 18.48 \\
\cline { 2 - 3 } & Communicate & 17.43 \\
\hline
\end{tabular}

Table 3 shows that most of the students of SHS and
VHS in Bandung City do not have optimal peace culture. seen from a student of VHS the proportions of the culture peace of value based on al-Quran spread in six dimensions, with a dimension sequence of restraint, peace, humble, forgive, collaboration, and communicate. Student of SHS the proportion of the culture peace of value based on al-Quran spread in six dimensions, dimension sequence collaboration, communicate, forgive, peace and restraint.

Associated with the results of the study of references [3, 16], students basically have an effort to create a culture of peace in the context of the classroom learning process and create conducive classroom conditions. In addition students have a direction to change the mindset in resolving differences with classmates who are characterized by not doing violence so students feel safe and comfortable to study in school, and students are encouraged to develop the knowledge, skills, values, and attitudes of peace that have been done and cultivate peace in class or school, family and community environment [19, $20]$.

The importance of the culture of peace in schools is put forward by references $[3,20,21]$ explaining that the "essence of a new humanity" which represents a culture of peace will build a mindset, order of thought, and peace towards the developmental approach [4, 22, 23].

Table 4. Major Value Based on al Quran

\begin{tabular}{clc}
\hline Values & \multicolumn{1}{c}{ Description } & Reference al Quran \\
\hline Restrain & $\begin{array}{l}\text { Then forgive and let them so that the gods bring in orders. Indeed } \\
\text { Allah, over all things all-powerful }\end{array}$ & Chapter 2, verse 109 \\
\hline Forgive & $\begin{array}{l}\text { It is by the grace of God, you be gentle with them. If you (O } \\
\text { Muhammad) to be rude, rough hearts, they will get away from you. }\end{array}$ & Chapter 3, verse 159 \\
\hline Humble & $\begin{array}{l}\text { Representing advising and argue that constructive and } \\
\text { argumentative, in addition to the values of the Qur'an provides } \\
\text { guidance that an individual should have the principle of wisdom } \\
\text { (Al-Hikmah), good advice (Al-mawizah, al-hasanah), and debate the } \\
\text { best method, as mentioned in the Quran }\end{array}$ & Chapter 16, verse 125 \\
\hline Communicate & $\begin{array}{l}\text { And if there are two classes of those who believe that war is } \\
\text { reconciled them both. }\end{array}$ & Chapter 49, verse 9 \\
\hline
\end{tabular}


Associated with al-Quran Values is an entity that is not only viewed from aspects of world life with its various conveniences and challenges but should be comprehensive since humans were created, turned on, born, turned off until one day revived from their deaths and happy world and the hereafter. Peace is reflected through the letter of chapter 2, verse 201,

"And among them, there are those who pray: Our Lord, give us goodness in the world and goodness in the Hereafter and protect us from the torments of hell."

Building an effective culture of peace, competition and improving the quality of behavior can only be done if the individual views and realizes that the culture of peace must be carried out throughout life. There are three aspects that must be considered by each individual in life, namely the knowledge base learning as a learning society that requires education and training in a lifelong learning system. This means that the learning process will always be attached to each individual's life that takes place in the context of an ever-changing environment. Learning to live together (Learning to Live Together) is expected to be able to fight prejudices that can lead to disputes.

Allah SWT also advised through the letter of chapter 3, verse 105 ,

"And do not be like those who divorce and disagree after arriving at them a clear statement."

The values in the holy book of the al-Quran that peace is one form of learning to live together (Learning to Live Together) which has the meaning of being able to fight prejudices that can lead to disputes. For this reason, Allah SWT said as explained in the letter of chapter 5, verse 14,

"And among those who said:" We are Christians ", We have taken their covenant, but they (intentionally) forgot some the message that had been warned to them, then We caused hostility and hatred between them until the day apocalypse."

Furthermore, Allah SWT also advised through the letter of chapter 3, verse 105,

"And do not be like those who are divorced and disagree after arriving at them a clear statement."

When paying attention to the two words of Allah SWT, it illustrates that the process of developing a culture of peace must take two complementary sides, on the one hand the peace culture is carried out in the learning process that must increase individual understanding of others, on the next side the peace culture is carried out in the learning process who must facilitate individual experiences in collaborating and dealing with others in achieving lifelong shared goals. This learning process is the right way to develop a culture of peace in school.

The findings of the study first regarding peace culture based on the al-Quran values on the forgiveness dimension of 112.23 are quite good and significant; this is based on the assumption that on al-Quran creating a peaceful culture-based value requires a gradual and long-term process. In building a culture of peace in the dimension of forgiveness, students should have moral values, namely respect or respect, and courtesy. This is in accordance with the study of references $[1,24]$, “... the two universal moral values of the core of the public, teachable morality: respect and responsibility", represent that respect, acceptance, and sports, accept happily and accepting sincerely is a way to live and survive in groups.

The results of the study of references [17, 20, 25] explain the dimensions of forgiveness that students have will have an impact on students to

1) achieve their life goals and improve their quality of life;

2) get life satisfaction and happiness;

3) characteristic of achieving teacher and school goals;

4) get welfare in his life;

5) building trust and acceptance among students;

6) encouraging social ties, providing benefits from positive social interactions for recipients and providers who do and enabling donors to use and develop their personal skills for themselves and others.

The findings of the study second regarding the culture of peace based on al-Quran values on the dimensions of 47.64 meeknesses are not optimal, the findings of this study are in line with the results of the study of references $[1,3,21]$ explaining that the dimensions of meekness are dimensions for encouraging and pursuing individuals have aspects of peace culture skills, including

1) reflection that is the use of reflective thinking or reasoning, where they deepen their understanding of themselves and their connection to people to live in the world;

2) critical thinking and analysis, namely the ability to approach problems with an open mind but still with critical thinking;

3) decision making namely the ability to analyze problems, develop alternative solutions, analyze alternative considerations of advantages and disadvantages and the ability to prepare plans for implementing decisions;

4) imagination, namely making and imagining new paradigms and preferred new ways of life,

5) communication, namely listening attentively and with empathy, and the ability to express clear ideas and needs and in a non-aggressive way;

6) Conflict resolution is the ability to analyze conflicts objectively and systematically and suggest various non-violent solutions. Conflict resolution skills include proper assertiveness, dialogue, active listening and collaborative problem-solving. Communication skills are basic skills in resolving conflicts;

7) empathy is the ability to see individual and group perspectives and feel what individuals or groups feel. 
Empathy is a skill that helps in expanding students perspectives especially injustice and constructive;

8) group building which is working cooperatively with one another to achieve common goals. The assumption is that everyone has something to contribute; everyone is part of the solution.

Reinforced results of human studies need to have a gentle attitude towards others, forgive and discuss each other in resolving an affair [13], as stated in the Qur'an chapter 3 , verse 159 ,

"Then by the grace of God, you are gentle towards them. If you (O Muhammad) are rude, miserable, surely they will stay away from you. So forgive them, ask forgiveness and consult with them in matters (war, economy and other world affairs). When you have resolved your resolve, trust God (in carrying it out without hesitation). Indeed God loves those who believe in Him".

\subsection{Psychological Dynamics of Peace Culture Based on Al-Quran Values}

Findings of students' psychological dynamics seen in dimensions of meekness indicate that students lack courtesy courtesy, student attitudes are seen when the teacher enters, some students immediately throw spontaneously "eh aya si eta, hoream pisan di ajar ku si ibu"; "maneh gandeng itu aya ibu", there were even students who immediately asked permission to leave the class on the grounds of confirming their veils, and the teacher said "dandan wae atuh, jiga artis" at the same time students in the class laughed.

When the learning process takes place, it appears that students ask the teacher with the language to their friends, for example "bu apa itu teh maksudnya, daaaa ngga jelas" and the learning process is over, students say "bu kemana lagi, mau nanyain tugas yang praktek" and the other students responded immediately with the phrase "maneh ih nanya wae ka si ibu, keun we gimana ibu, iyaaa kan bu". Lack of respect for students to the teacher feared indicated the occurrence of conflict, implicitly the sense of respect and trust of the teacher arises when students call the name of the mother/father teacher but the interaction of teachers and students tend not to create a climate of peace in the dimension of love.

The research findings show that the dimensions of deliberation between students and teachers are well interwoven, for example there are several students telling each other the barriers and pressures they have to the teacher/homeroom teacher, the words that were uttered " $b u$ mau cerita lagi, kemarin ada kejadian yang buat saya jadi bingung, kapan bu?" and "maneh kenapa diam aja, diputuskeun sama kabogoh?", the statement indicates students have an attitude of attention and openness to help each other and share stories, but the words uttered seem rougher, and if others hear it will hurt or can lead to conflict.
Other findings were interesting in the class; the average female student admitted that if their homeroom lessons showed a happy, relaxed and calm attitude. However, if their mathematics lesson addresses endurance to pay attention to the teacher and do the tasks less optimally or weakly motivated, the impact is that they are more likely to play cellphones or mirrors to use lipstick or justify a veil.

Class condition began rowdy, after the break completed and subject teachers have not been to class, a sentence that was brought students in the class is very diverse as "maneh beb, aing pinjem hp kamu, mau minta tetering", "ieu $h p$ saha, urang mau cas hp gantiannya", "kamu kenapa tidak pake sepatu, jatuh dari motor? nyeri teu" immediately answered "nyeri ari maneh". There was even one student who dared to disturb his friend who was working on the task with ridicule, the words uttered "maneh ngerjakeun naon? sok rajin pisan sia". It appears that the language distortion is rough and is usually done by students.

In the dimension of peace, students show sensitivity to the needs of others characterized by students helping each other if students forget to bring pens or pencils by lending their stationery, and sensitively bring sick students to UKS or deliver home. The research findings of the majority of female students in high school are classified as middle to lower class, but the behavior shown by students is very excessive, which is marked by several students dyeing their hair, putting on makeup with prominent appearance (wearing red lipstick, tight clothes and wearing shoes that do not match regulations), even researchers had time to open Instagram media accounts, there was one student wearing disrespectful clothes, daring to be different from other people, and photos taken at the club's night scene, having an impact on students having weak morals and often making conflicts in class or outside school. And it is difficult to create a culture of peace, the language spoken by rude female students, weak manners and respect.

In the dimension of communication, the psychological dynamics shown by students are characterized by students having or collaborating with each other in completing tasks in groups well and thinking positively, words uttered by students such as "coba semuanya saling berbagi tugas, maneh kerjakan dulu nomor satu, dan kamu nomor 2 dst, nanti kita saling koreksi yah", students address attention to the common good such as paying cash on time, clearing the class after the learning process is complete; and in the class no majority groups are smart or rich, class conditions are more fun and enjoyable. During class breaks, it is never empty, students take turns and believe to maintain classes, and students direct attention and help those who look after the class by buying food and drinks. Furthermore, the research findings show that the majority of students in the class possessed a caring attitude towards his fellow friends, which is characterized by asking the condition of the news, once touted as "kemarin kenapa ngga masuk sekolah", "ada yang mau titip makanan ke kantin", the student concerned look the condition of friends who are sick, and students care about cleaning the class to create a healthy 
and clean environment.

The findings of the study on the culture of peace based on al-Quran values show that students pay less attention when the teacher speaks, the behavior shown by students playing the cellphone or taking or borrowing a small mirror to justify the appearance of using lipstick or justifying a veil. Students have not been able to eliminate the habit of talking when talking to friends, things that are not good for students to do, even though the class is all-female, but talk or speech that is spoken rudely, for example, "how come, you talk first and how come". In addition, the teacher's words and actions should be reassuring. On the contrary, there are some teachers who often give judgment or angry attitude that makes children become less serious in learning, even trying to skip the lesson. But the culture of peace is based on the values of the al-Quran that are shown by students such as students feel part of the class, close friendship, cooperate with each other, give mutual support, be forthright or open, the atmosphere of the competition does not damage friendships, does not distinguish friends based on background provide a good and peaceful atmosphere.

The findings of the study from the results of statistical significance show that the culture of peace based on the al-Quran values is not yet optimal, and in a manner then, the practical al-Quran peace culture-based values have not shown the psychological dynamics of the culture of peace based on the values of the al-Quran. Teachers as peace educators should show a peaceful mindset and behavior, but the findings of teacher research have not been optimal in finding ways or strategies to create a culture of peace based on al-Quran values, which are characterized by teachers seeming to pose a threat to disturbing or noisy students during class the learning process takes place, cannot do assignments or is noisy in the classroom, the words uttered by the teacher when they find students are disturbing or noisy in the classroom, such as "kamu yang duduk sama A, sedang berdiskusi apa, dari tadi mengobrol terus, mau saya keluarkan dari kelas ?", "hey..hey.. kalian kaya anak SD berisik terus", "diam atuh, berisik saja (while hitting the desk in the classroom) "silahkan ke depan, kerjakan soal nomor sekian (with high notes and faces the angry one)". The results of the interview with one teacher, when there are students who want to fight or conflict occurs, the first greeting is made, "coba kesini nak, sok kalian duduk, ada apa? dari jauh kalian saling bicara kasar, ini bukan kebun binatang tapi sekolah." The behavior shown by the teacher indicates that the teacher understands the condition of the student in the classroom, but has not shown respect or empathy optimally, the language conveyed to students' leads to identifying or exploring problems even poses a threat to students.

\section{Conclusions}

The results of the existing condition study in several
SHS and VHS in the city of Bandung Indonesia showed that most of them were at a moderate level of $57.07 \%$ and as small at very low levels of $3.36 \%$. Most of the grade students of several high schools in Bandung City do not yet have an optimal peace culture, seen from the proportions of the culture of peace based on the values of the al-Quran spread in six dimensions, with a dimension sequence of forgiveness, peace, restraint, communication, deliberation, and meekness. Based on the results of research on peace culture based on al-Quran values, the implications are as follows.

Peace culture based on the values of the al-Quran is a systematic effort and synergy is carried out by education between students, teachers and school stakeholders. In the dimensions of the culture of peace based on the values of the al-Quran in the classroom can be applied every lesson in class is designed to inspire students to explore the culture of peace based on the values of the al-Quran, and different learning models, take inspirational activities, discuss and conduct guidance to provide opportunities for students to assess how they can behave in their daily lives.

In creating a culture of peace based on the values of the al-Quran, teachers and educator stakeholders should be role models in either acting or speaking in a constructive direction, so the climate of the peaceful class will slowly move in a better direction. In addition, a strategy to create a culture of peace based on al-Quran values is a guideline that should be understood and applied by the teacher.

\section{Acknowledgements}

We are grateful to Universitas Pendidikan Indonesia who has provided us with a grant to do this research. We are also thankful to all schools and teachers who have shared their voices and experiences with us.

\section{REFERENCES}

[1] S. Kartadinata, U. Suherman, Ilfiandra, I. Saripah, R. Setiadi, E. Ropo, \& E. Syrjäläinen. Exploring the values of peace in the cultural contexts of Indonesian and Finnish schools: A study of the development of peace pedagogy. Man in India, Vol. 96, No. 5, 1485-1504, 2016. https://doi.org/10.2174/1 874350101710010182

[2] G. Jun. Transforming Conflict: A Peacebuilding Approach for an Intergroup Conflict in a Local Congregation. Transformation, Vol. 35, No. 1, 1-14, 2018. https://doi.org $/ 10.1177 / 0265378818767675$

[3] Jasmin Nario-Galace \& Loreta Navarro-Castro. Peace education: a pathway to a culture of peace. Journal of Peace Education, Vol. 8, No. 3, 357-358, 2010.https://doi.org/10 $.1080 / 17400201.2011 .589504$

[4] J. Galtung. (1967). Theories Of Peace A Synthetic Approach to Peace Thinking. In International Peace Research Institute 
Vol. 1. Retrieved from https://www.transcend.org/files/Gal tung_Book_unpub_Theories_of_Peace_-_A_Synthetic_Ap proach_to_Peace_Thinking__̄ $19 \overline{67}$.pdf

[5] Z. Gross. Revisiting peace education: Bridging theory and practice - International and comparative perspectives Introduction. Research in Comparative and International Education, Vol. 12, No. 1, 3-8, 2017. https://doi.org/10.11 77/1745499917698290

[6] Komisi Nasional Anti Kekerasan Terhadap Perempuan (2016). Kekerasan terhadap Perempuan Meluas: Negara Urgen Hadir Hentikan Kekerasan terhadap Perempuan di Ranah Domestic, Komunitas dan Negara. Lembar Fakta Catatan Tahunan (Catahu) 2016, pp. 1-5. Retrieved from http://www.komnasperempuan.go.id/lembar-fakta-catatantahunan-catahu-2016-7-maret-2016/

[7] B. Himmich. (2011). Revisiting the intercultural dialogue in the light of a culture of peace. Diogenes, Vol. 58, No. 4, 39, 2011. https://doi.org/10.1177/0392192112471598

[8] D. Adams. UNESCO and a Culture of Peace: Promoting a Global Movement. UNESCO Publishing. Paris, France, 1997.

[9] M. I. Yousuf, M. Sarwar, G. Dart, \& M. Naseer-ud-Din. Peace Perceptions of Prospective Teachers for Promoting Peace Activities for School Settings in Pakistan. Journal of College Teaching \& Learning (TLC), Vol. 7, No. 3, 53-58, 2016. https://doi.org/10.19030/tlc.v7i3.103

[10] V. Sharma. Peace Education and Human Rights in Twenty-First Century : a Review. International Journal of Social Science \& Interdisciplinary Research, Vol. 1, No. 12, 197-203, 2012

[11] D. Adams. Toward a global movement for a culture of peace. Peace and Conflict: Journal of Peace Psychology, Vol. 6, No. 3, 259-266, 2004. https://doi.org/10.1207/s15327949p ac0603 9

[12] H. Cremin. Peace education research in the twenty-first century: three concepts facing crisis or opportunity? Journal of Peace Education, Vol. 13, No. 1, 1-17. 2016. https://doi.org/10.1080/17400201.2015.1069736

[13] U. Suherman. (2018). Bimbingan Dan Konseling Komprehensif Berbasis Nilai-Nilai Al-Quran (1st ed.; D. Suryana, Ed.). Retrieved from http://ppb.upi.edu/bimbinga n-konseling-komprehensif-berbasis-nilai-nilai-quran/

[14] I. Ismail. Character Education Based on Religious Values: an Islamic Perspective. Ta'dib, Vol. 21, No. 1, 41-58, 2016. https://doi.org/10.19109/td.v21i1.744

[15] U. Lau, \& M. Seedat. Towards relationality: Interposing the dichotomy between peace and violence. South African Journal of Psychology, Vol. 43, No. 4, 482-493, 2013. https://doi.org/10.1177/0081246313508350

[16] S. M. Lauritzen. Building peace through education in a post-conflict environment: A case study exploring perceptions of best practices. International Journal of Educational Development, Vol. 51, 77-83, 2016. https://doi.org/10.1016/j.ijedudev.2016.09.001

[17] M. F. Farahani. The Role of Global Citizenship Education in World Peace and Security. Procedia - Social and Behavioral Sciences, Vol. 116, 934-938, 2014. https://doi.org/10.1016 /j.sbspro.2014.01.323

[18] Creswell W. John. Research Design: Qualitative, Quantitative, and Mixed Methods Approach 3rd Edition. Sage Publications, Inc. Thousand Oaks, US, 2009. https://doi.org/10.2307/1523157

[19] A. Cromwell. How peace education motivates youth peacebuilding: Examples from Pakistan. International Journal of Educational Development, Vol. 66, 62-69, 2019. https://doi.org/10.1016/j.ijedudev.2019.02.006

[20] R. Z. Shehi, S. Ozcan, \& T. Hagen. The Role of Higher Education Institutions in Building a Culture of Peace: An Albanian Case. Journal of Peacebuilding and Development, Vol. 13, No. 1, 46-61, 2018. https://doi.org/10.1080/15423 166.2018 .1427136

[21] D. Wahyudin. Peace Education Curriculum in the Context of Education Sustainable Development (ESD). Journal of Sustainable Development Education and Research, Vol. 2, No. 1, 21-32, 2018.https://doi.org/10.17509/jsder.v2i1.123 54

[22] J. Galtung. A Structural Theory of Imperialism. Journal of Peace Research, Vol. 8, No. 2, 81-117, 1971. https://doi.org/10.1177/002234337100800201

[23] I. Gur-Ze'ev. (2010). Peace education. In International Encyclopedia of Education. https://doi.org/10.1016/B978-0 -08-044894-7.00542-X

[24] Z. Bekerman, \& M. Zembylas. Some reflections on the links between teacher education and peace education: Interrogating the ontology of normative epistemological premises. Teaching and Teacher Education, Vol. 41, 52-59, 2014. https://doi.org/10.1016/j.tate.2014.03.002

[25] L. D. Paderanga. Classroom Video Conferencing: Its Contribution to Peace Education. Procedia - Social and Behavioral Sciences, Vol. 123, 113-121, 2014. https://doi.org/10.1016/j.sbspro.2014.01.1404 